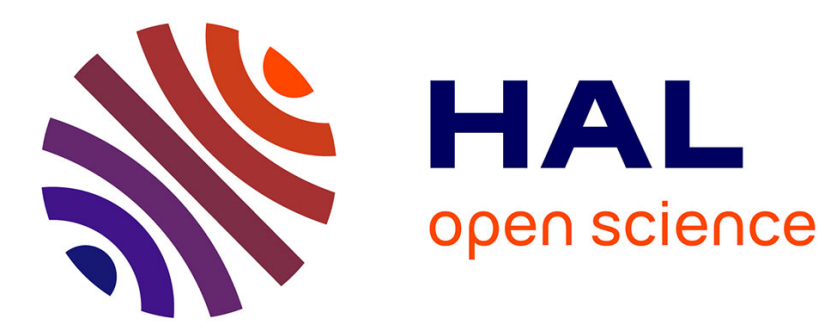

\title{
Interweaving Objects, Gestures, and Talk in Context
}

Christian Brassac, Pierre Fixmer, Lorenza Mondada, Dominique Vinck

\section{To cite this version:}

Christian Brassac, Pierre Fixmer, Lorenza Mondada, Dominique Vinck. Interweaving Objects, Gestures, and Talk in Context. Mind, Culture, and Activity, 2008, 15 (3), pp.208-233. halshs-00337838v2

\section{HAL Id: halshs-00337838 \\ https://shs.hal.science/halshs-00337838v2}

Submitted on 9 Nov 2008

HAL is a multi-disciplinary open access archive for the deposit and dissemination of scientific research documents, whether they are published or not. The documents may come from teaching and research institutions in France or abroad, or from public or private research centers.
L'archive ouverte pluridisciplinaire $\mathbf{H A L}$, est destinée au dépôt et à la diffusion de documents scientifiques de niveau recherche, publiés ou non, émanant des établissements d'enseignement et de recherche français ou étrangers, des laboratoires publics ou privés. 


\title{
Interweaving Objects, Gestures, and Talk in Context
}

\author{
Christian Brassac \\ Equipe Codisant, LabPsyLor \\ University of Nancy2, France \\ Pierre Fixmer \\ Equipe Codisant, LabPsyLor \\ University of Nancy2, France \\ Lorenza Mondada \\ ICAR Laboratory (CNRS) \& \\ University of Lyon, France \\ Dominique Vinck \\ PACTE \\ CNRS / Grenoble Universities, France
}

\section{Introduction}

This paper focuses on the articulation between collective activities, objects, and multimodal resources. Discussing recent theories on action, activity, interaction, and social practices, it points out the fact that although the ecology of action is becoming a key topic in various disciplines, studies that explicitly take artifacts and gestures into account - both theoretically and empirically - as they are actually mobilized by participants in interaction have remained underdeveloped. This raises some questions about the praxeological definition of these objects and multimodal resources, and the way in which an empirical analysis can deal with them.

In this paper, we will propose an interdisciplinary attempt to articulate objects, gestures, and talk within collective activities in context. We will do this by presenting a general discussion of contemporary paradigms dealing with activity (Section 1: An Interdisciplinary Framework for Rethinking Activity) and recognizing the importance of artifacts (Section 3: Objects in Action ), and we will do so not only by reviewing existing proposals, but also by tackling an empirical case, the introduction of computarized medical records at a hospital (Section 2: An Empirical Case: Implementing Computarized Records in a Hospital). Our analysis of a meeting about the project (Section 4: "Prescription" versus "Ordonnance") will provide an empirical opportunity to discuss the interrelationship between the definitions of various kinds of artifacts, and multimodal collective practices. 


\section{An Interdisciplinary Framework for Rethinking Activity}

In the contemporary social sciences, various paradigms are proposing innovative ways of rethinking activity in their context. We will consider them according to how they take into account not only situated social activities, but also the very ecology of those activities, which includes the spatial arrangement of the participants, their embodied action, and their use of various material resources such as objects, documents, and technologies.

Action as a topic of study emerged in the early twentieth century. It became an established issue in the 1950's in the United States, and then between the 60's and 80's, was extended to include interaction, viewed from various perspectives including social pragmatism (Mead, 1934), symbolic interactionism and it heirs (Goffman, 1971), ethnomethodology (Garfinkel, 1967), and pragmatics in linguistics. Today, four approaches provide the architecture for this field of research: the first two are mostly psychology-based, the other two are sociology-based.

Among the various paradigms, we will briefly consider Activity Theory (Engeström Miettinen, \& Punamäki, 1999), ethnomethodologically-inspired Conversation Analysis and more specifically workplace studies and situated action as developed by Suchman (1987), Actor-Network Theory, and the various models of Distributed Cognition from Lave (1988) to Hutchins (1995). These paradigms have contributed to the emergence of a praxeological approach to human conduct; they all stand apart from the mentalistic perspective and propose various ways of tackling the question of artifacts in social practices (see Section 3 below).

Activity Theory is a cross-science theory for studying humans as actors in a culturalhistorical context, and for examining the different forms of praxis as a developmental process. It is based on the idea of a dual process whereby humans and artifacts are shaped and formed by the social and physical environment. It interlinks the individual and the social levels simultaneously. The theory has its origins in eighteenth century German philosophy, in the historical tradition of cultural psychology (Völkerpsychologie), which encompasses the writings of Marx who developed the notion of activity, the Soviet Russian cultural-historical psychology of Vygotsky, Leont'ev, and Luria (Cole, 1996), and American pragmatism, especially the works of Dewey and Mead (Engeström \& Miettinen, 1999). One can discern several theoretical generations in the evolution of Activity Theory. First, Vygotsky developed the idea of mediation. Then, Leont'ev integrated other human beings and social relations into the concept of activity. He distinguished three levels of activity in a dynamic relation: activities, actions, and operations. Later on, Engeström proposed a graphic depiction of his model of the collective activity system. Today, a multitude of applications of activity theory have begun to emerge, and the basic model has been expanded to include at least two interactive systems (Engeström, 2000). In Activity Theory, the subject's orientation towards an object shapes an activity. Activities are distinguished by the objects and tools they involve, and by the rules that determine collective action within and beyond the division of labor, which also contribute to the system's history. The theory takes a object-oriented, artifact-mediated collective activity system as its unit of analysis. It integrates contextual changes and individual development into its dynamic view. In this manner, the individual subject and the societal structure are linked. From the standpoint of Activity Theory, artifacts are mediators of human thought and are in the service of activity. Applications of Activity Theory to various fields have demonstrated its potential for studying the usability of different kinds of technology as tools in people's everyday lives. 
The Distributed Cognition approach was developed by Edwin Hutchins and his colleagues in the mid- to late 1980's as a new paradigm for rethinking cognitive phenomena in all domains. The theoretical and methodological bases of the approach derive from the cognitive sciences, cognitive anthropology, and the social sciences. Distributed Cognition argues that human cognition can best be understood by considering it as a social-culturaltechnical phenomenon. The components of cognitive activity cannot be limited to mental representations, but must include social structures, culture, individuals, and tools. Human activity is not characterized solely by brain activity; on the contrary, the cognitive process is distributed across the members of a social group, across individuals and material or environmental structures, and across time (products of earlier events can transform the nature of later events). Distributed Cognition is able to highlight complex interdependencies between individuals, and between individuals and artifacts, in their collaborative activities. This perspective grants importance to an ethnographic approach, and its unit of analysis includes all elements of the setting without putting actors before artifacts. Unlike Activity Theory, Distributed Cognition accords an equal weight to human beings and material objects (artifacts) in understanding cognitive processes, although both paradigms see objects as the key to understanding social and cognitive activity.

A major focus of ethnomethodologically-inspired Conversation Analysis, launched in the 1960's by Harvey Sacks and Emanuel Schegloff, has always seen social activities as locally-situated practical accomplishments. In order to describe the central role of these practices and the procedures (or methods, according to Garfinkel [1967]) that organize them, Conversation Analysis is based on empirical data constituted by naturally occurring interactional events that have been audio- or videotaped. Recordings of this sort are aimed at preserving the fundamental temporal and praxeological features of the activity, which are indispensable for its analysis (Mondada, 2006). The recorded data undergo a fine-grained transcription. Both the recordings and the transcriptions provide the details participants attend to in order to locally accomplish the organization of their actions and the production of their accountability. Thus, these details are not just used by researchers to empirically support their analysis; rather, they are considered first and foremost as they are treated in an endogenous way by the participants as they give order, intelligibility, and coherence to their social actions. Analyses focusing on these locally relevant details have been elaborated within the frameworks of ethnomethodology and Conversation Analysis, although these two fields are much more distinct today. Both have inspired a number of different approaches to conducting detailed analyses of work activities, such as the study of talk in interaction in institutional settings (Drew \& Heritage, 1992) which focuses on the organization of talk, workplace studies (Luff, Hindmarsh, \& Heath, 2000) which look more specifically at the organization of professional activities within complex spaces, technologically mediated environments, and multimodal practices, and ethnomethodological studies of work (Garfinkel, 1986), which are more ethnographically oriented. In this framework, the work by Suchman (1987), deeply inspired by Garfinkel's reading of Wittgenstein, has crossed over into a number of these fields (for instance, via its participation in workplace studies) and has been labelled situated action, now influential for researchers in ergonomics and in situated and distributed cognition. Suchman's study (1987) was one of the first to introduce into this intellectual framework the importance not only of talk but also of objects and situated elements within courses of action such as problem solving, which in this study takes place around a photocopy machine. In studying how users interact with the photocopy machine, Suchman points out the importance of the indexicality of action and critically re-specifies the role of plans, not as determining action but as a resource for action. 
Actor-Network Theory has its origins in sociology and in the anthropology of the sciences, initiated in the 1980's by Bruno Latour and Michel Callon. It focuses on setting up relations and networks without any a priori distinctions between the involved entities, whatever their qualities and their human or non-human nature. Relations are the result of a translation process in which each entity moves. They mutually redefine and engage each other. From relation to relation, a heterogeneous sociotechnical network emerges, which can be limited or extended, and which can be interconnected in a hard-and-fast or slack way. When the network is highly interconnected, it evolves as a new entity or a new actor (actornetwork). Any entity can be considered as a network in itself. For instance, a scientific statement is the summary of a sociotechnical network. In the same way, a machine, a human being, or an organization can be seen as a network. The Actor-Network Theory approach focuses on practices for sociotechnical network building. It requires the observer to avoid any a priori asymmetries (for instance, between the human and the non-human) and to follow associations without any a priori limitations. Two major methodological principles are: follow actors and artifacts from one point or place to another (do not confine oneself to a specific situation), and think symmetrically (give equal consideration to winners and losers, truths and beliefs, humans and others, innovators and users, etc.).

These paradigms vary not only in their epistemological premises or analytical mentalities, but also in how they approach empirical data and actually define the very data on which they work. In the next section, we will emphasize the way in which these various methodological insights have inspired our interdisciplinary approach to an empirical case.

\section{An Empirical Case: Implementing Computarized Records in a Hospital}

The implementation of a new computer device in a professional and institutional milieu is an exemplary and perspicuous (Garfinkel \& Wieder, 1992) setting to observe when interested in the intertwining of technologies, practices, objects, and participants. Among other professional and institutional settings, hospitals are an ideal place for doing fieldwork because of their complex organization, fragmented activities, and heterogeneous participants (Keating \& Cambrosio, 2000; Strauss, Fagerhaugh, Suczeck, \& Wiener., 1985). In the medical context, formalizing procedures in order to introduce electronic records or computerbased decision tools may involve many obstacles and often generates considerable resistance (Berg, 1997) among a large number of heterogeneous yet autonomous actors who are difficult to enroll (Callon \& Law, 1982). Even defining the tasks or entities to be formalized and computerized, which necessitates negotiation to obtain widespread agreement, can take a very long time.

In what follows, we will focus on a specific case, the computerization of medical files in a large French hospital. The aim of this technological innovation was to secure the traceability of blood products by developing an electronic medical record for each newly hospitalized patient. The creation of a unique electronic record for each patient that would store all transfusions and blood products he or she would receive was designed as a solution to the huge problems caused by poor traceability of blood products (only 96\%), ending in the disappearance of thousands of products.

This case was approached through a variety of field methods. Attempts to introduce computarized patient records have been going on for six years, but the process is still not finished since such records have not yet been implemented. For one year, fieldwork was carried out: field notes were taken; participant emails, written documents, minutes of 
meetings, slide shows, and copies of screens circulating among the actors were collected; and interviews were conducted with various actors with different responsibilities and perspectives within the project. In the entire history of the project, the representatives of the involved entities met only once, and this meeting was videotaped.

The corpus that attempts to document this project, although rich, is therefore partial, fragmented, and heterogeneous. If the observers had only partial and limited access to the unfolding of the project, this was even more so for the participants themselves, whose picture of the situation was much more incomplete and often relied on fragments of information provided by the observers as they tried to understand what was going on. On the other hand, the participants had some information and knowledge the observers did not get. Many documents produced by the actors were included in our corpus, but the actors also used some of the documents we produced, such as interview summaries or narratives of the project's history. The corpus thus played a part in the development of the events, reflexively contributing to shaping the local understanding of the project and the generation of meaning.

In this paper, we will focus on the videotaped meeting in which the medical staff, the computer engineers, and the administrative personnel of the hospital are discussing the state of the project and negotiating the tasks to be accomplished and the objectives to be met.

Since 1993, French law requires hospitals to draw up and save a single blood transfusion record for every patient. At the time that our fieldwork was carried out at Vinatier Hospital, records were being produced by every hospital department where the patient entered, and were kept in the patient's paper file specific to individual wards. Thus, records were not shared among departments, and the history of antecedents was lost. However, a discussion was held regarding the possibility of computerizing patient files, which was seen as an opportunity to develop blood transfusion database shared by all hospital wards. The implantation of such a database was complicated by various problems (i.e., traceability of blood products, traceability of the patient's medical history, data protection and access, data exchange between blood-product suppliers and hospitals). In March 1996, while waiting for further developments regarding electronic records, the hospital hemovigilance commission set up a procedure using paper files only, at the same time as a work group started discussions among hospital system departments and blood suppliers. Even though the latter were considered a national leader in the field, they faced problems of data incompatibility and the negotiations were stopped.

Regarding the electronic blood-transfusion records, the physician at the head of the hemovigilance service defined the specifications, and acted as a mediator between the director of data processing and the hemovigilance commission. The latter presented and discussed a first model in December 2001. A few weeks later, the hospital was audited for quality certification. Because the auditors were very critical regarding the blood-transfusion records, the hospital director wrote a mission letter in January 2002 and set up a project group to solve the problem. The group was run by the president of the hemovigilance commission (Dr Lamblet), the director of data processing (Mr. Steiner), and the head of the hemovigilance department. Many e-mails were circulating at this period among the medical staff, but no formal meetings were held. Through these informal interactions, medical doctors and system engineers re-defined the problem and agreed on a solution. A new model for electronic records began to circulate, and the data processing department started development. In April, a computer engineer gave a power point presentation of the model in front of the hemovigilance commission, and then during the summer, a prototype was tested in a resuscitation unit in which Dr Régnier works. From the doctors' and the nurses' points of view, the experiment failed. There were no meetings between computer engineers and 
practitioners until several months later when, thanks to the mediation of the head of the hemovigilance department, the actors (from the resuscitation unit, data processing staff, and the hemovigilance department) agreed to meet in the presence of a sociologist who videotaped the event.

The intertwining of intermediary objects (many e-mails, drafts of procedures, minutes of meetings, powerpoint presentations, "sheets in use" or prototype sheets of the patient file, computer screens, etc.), talk and actors evolved throughout the project. What appears in the excerpts quoted below is only a part of these entities, including objects entering into the scene for the first time.

The meeting is thus the unique occasion where representatives of the various groups involved in the project are co-present and can assess areas of agreement and disagreement, by way of a discussion organized not only by verbal resources, but also by body movements and gestures, and by showing, exhibiting, and putting on the table various artifacts that create complex links with the electronic medical record being discussed. The electronic record and the computerized device are complex entities, materialized in software, in printed records, in extra-technological objects, in ways of using the computer, and in ways of organizing ordinary work around the file; the virtual electronic record is an entity that travels around to various places, going from the computer of the engineers designing the system to the computer of the doctors and nurses who use (or do not use) it, and to the addressees of the blood product orders, etc. The electronic medical record links very different contexts, people, objects, and problems, and the aim of the meeting is to determine to what extent these links are working, could work, or will never work. In this sense, the meeting brings into play a number of relationships between the entities that are abstractly or materially related within the project.

Let us now introduce a first excerpt of this meeting. Its analysis will provide a basis for tackling the question of objects and artifacts, as well as questions related to the unavoidable choices that have to be made when presenting such a corpus and the reasons for focusing our analysis on this particular moment. (Our transcription conventions are explained at the end of the paper.)

Excerpt 1 (tape 1/9'20)

1 LAM le système en lui-mêmel est-ce que tu d- tu tu disais que the system itself were you say- were you you saying that

2 par rapport à la prescription papier c'était c'était la compared to prescriptions on paper it was it was the

3 prescription papier était simple/ on collait les étiquettes/

4 REG hum prescriptions on paper were simple/ you stuck the labels on/

5 LAM on remplissait/ (.) .h est-ce que: par rapport une fois quand you filled in/ (.).h is it: concerning once

6 tu es sur l'ecran/ euh de: de commandel you're on the screen/ uh for: for ordering $\backslash$

7 REG ${ }^{\circ}$ oui $^{\circ}$ ${ }^{\circ}$ yes $^{\circ}$

8 LAM abstraction de ce qu'y a avant pour y accéder/=

9 REG =oui: disregard what's before to get to it/= $=$ yes: 
10 LAM de ce qu'y a après/ et des problèmes de l'EFS*` une fois que what's after/ and problems with the EFS once you

11 t'es d'ssus/ est-ce QUE: la prescription/ est simple ou compliquéel you're on it/ is IT: the prescription/ simple or complicated

12 REG euh une fois qu'on est euh sur l'é[- l'écrAN/

13 LAM uhonce you're uh on the s-the screen/

14 REG c'est:: 1- la prescription est facile/ il faut cocher le it's:: th- the prescription is easy/ you have to check off the

15 nombre de de de produits sanguins/ eh de concentrés

16 euh [c'est uh [it's

17 LAM [alors j'te pose une question tout d'suite/ [so I'll ask you a question right away/

18 ((asks a question and gets an answer, 12 lines omitted))

30 LAMalors $\backslash$ le le le parce que si j'ai bien compris le tu dis sol the the the because if I understand right you're saying

31 que la commande est relativement simplel that ordering is relatively simple

32 j'essaie pas de de: (.) de défen[dre qui que ce soit 33 REG I'm not trying to to:(.) to defen [d anything at all

34 LAMj'essaie simplement de faire un bilan des choses $\backslash$.h tu I'm just trying to get the big picturel .h you

35 dis que le système est relativement simple à utiliser pour

say the system is relatively easy to use for

36 faire la commande/ euh:: donc madame Richter dit que (.) POUR 37 les infirmières y a (quand même)/ simplement sur la saisie

38 du code à barre une simplicité de fonctio[nnement

39 RIC the bar code it's easy to [operate

40 LAM avec la douchette qui apporte quelque cho:se/ donc on

[avec la douchette

[with the douchette

with the douchette which adds some:thing/ so we

41 est/ (.) si on regarde simplement le nou- le le: le logiciel are/ (.) if you simply look at the co- the the: the software

42 en lui-même/ -fin le le le comment est-ce qu'on dirait itselfl -mean the the the what do you call it

43 le le kernel du [sy- le le

44 RIC? the the kernel of the [sy- the the

45 LAMle le noyau/ (.) du du système/ il a l'air de fonctionner/ the the corel (.) of the the system/ it seems to work/ le problème c'est son intégration en amont et en aval the problem is including it upstream and downstream

* EFS: French Blood Organization

This excerpt shows how Lamblet succeeds in (momentarily) obtaining from Dr Régnier an agreement about the "simplicity" of the device. However, coming to this agreement takes time - thus showing that it is to some extent problematic - and implies a 
series of reformulations of the problem that gradually transform it until it becomes acceptable. Lamblet's long speeches are characterized by a fragmented syntax with frequent insertions. For example, on line 1 he begins with a question, but then changes it into a declarative statement in reported speech; he reformulates the question on line 5, but again on line 8 and 10 inserts other considerations, delaying the question until line 11 and transforming it into a yes/no question. Interestingly, these insertions concern two fundamental features of the electronic record: (a) the difference between working on paper (2) and working on the screen (6), and (b) problems arising before and after the moment when the file is printed ( 8 and 10$)$.

After echoing the part of the question (12) that states the conditions under which he can answer positively (i.e., disregarding file-access problems), Régnier repeats the positive content of his agreement. This kind of answer contrasts with a simple "yes," which would implicitly ratify and accept all of the question's premises.

After a side sequence (omitted in the transcription), Lamblet again summarizes Régnier's position, where he reformulates his "the prescription is easy" (14) as "ordering is relatively simple" (31) and reformulates it again (35-36) after having inserted a justification (32). This time he doesn't wait for Régnier to agree but targets the agreement of the nurse, who answers with a collaborative sentence (39: she adds a prepositional phrase to his statement about the simplicity of the device). On this turn, Lamblet is using the terms "simple," "simply," "simplicity" in an overgeneralized way, concerning not only the device but also his ongoing evaluation of it.

Having obtained the local agreement of the doctor and the nurse, Lamblet can conclude that the "core seems to work" (45). This final assessment takes two minutes to be produced and secured. It requires questioning the doctor in quite an elaborate way, and before it can be obtained, some fundamental limitations about the clearly delineated domain the medical staff agrees to consider "simple to use" have to be formulated.

In this excerpt, the participants focus on both a difference between two material realms, the paper and the electronic record on the screen, and on an object, the "prescription," which moves back and forth between them but is nevertheless considered stable among them. Thus, although recognizing an important change between ways of working with paper and ways of working on the computer, the participants deal with the objects manipulated in these activities as if they were indifferent to their materializations. Moreover, in the discussion, an agreement is reached about the "simplicity" of the device. This agreement is based on a simplification of the objects, procedures, and context involved; it is based on an exercise consisting in abstracting the practical and detailed features that characterize the objects and actions as they are ordinarily managed. Thus, the agreement is reached about a fiction actively fabricated through discursive devices that disembody the objects and the everyday work.

In a way, what the participants have done here is what is routinely done within the social sciences, namely, ignoring the situated, embodied nature of work objects and gestures; in order to reach a momentaneous and fragile agreement, the participants are, for all practical purposes, producing disincarnated objects, i.e., objects simple enough to travel across contexts without changing, objects accomplished as "immobile mobiles" (Latour, 1985). In fact, the very next moment of the meeting will show that this disembodiment does not hold for long, that it is fragile and contingent, and will be radically problemized in the very next exchange. In an analogous way, we will argue that objects have to be treated in the social 
sciences with all their richness, complexity, and embodied depth in order to retain their efficiency within activities.

\section{Objects in Action}

The four fields of study briefly described above have been influential in the conceptualization of objects and artifacts within social practices. The viewpoint of each one will be presented while paying particular attention to the question of objects as "intermediaries," a notion borrowed from actor-network theory.

Distributed cognition has placed emphasis on the fact that cognition is not a purely mental kind of processing, but rather, takes place within a relationship to the surrounding world that is made up of concrete, material entities and is supported by the corporeal mobilization of the cognitive entity. This non-internalist view thus quite naturally leads one to consider the crucial role of the object in this externalization movement. When Hutchins (1995) studied the operator in action, he showed how the readout on a control panel fulfills a constitutive function of the operator's activity. As underlined by Nardi (1996), who insists that we not reject the computational stance of cognition, the process is distributed over the human entity (body and central nervous system) and the technical device (see also the special issue of Intellectica introduced by Brassac [2006]). The latter is thus considered to shape the cognitive process. In this field of study, then, the object is at the core of reflection on cognitive processes.

Kaptelinin (2005) stresses the complexity and the multiple uses of the term "object" in various versions of activity theory: he distinguishes the intended goal toward which activity is always oriented, in other words, Leont'ev's "predmet' or the artifact used to act, from Leont'ev's “object” (Leontiev, 1975/1984). It can nevertheless be stated that, according to activity theorists, activity mediates interactions between subjects (actors) and objects (as "physical things"). Mediation is achieved through the use of a set of cultural means. Their means consist not only of technical tools, which are artifactual structures, but also of signs, which are semiotic and psychological processes (Béguin \& Rabardel, 2000).

Even though conversation analysis started to develop with a strong emphasis on the organization of talk-in-interaction, as described on the basis of telephone calls and face-toface conversations (among other data), this research approach is also an analytical domain where systematic video analyses were developed very early on (see, for instance, the work by C. Goodwin in the US and C. Heath in the UK, already initiated by the late 1970's) (Goodwin, 1981; Heath, 1986). Video analysis makes it possible to consider not only the verbal resources that contribute to the interactional order, but also, and more broadly, multimodal resources including gestures, body behavior, gazes, and kinesic practices. As far as multimodality is concerned, the analysis focuses on technologies, artifacts, documents, and other objects, seen as material resources that are locally and contingently mobilized within the action and provide for its organization in both a systematic and indexical way. The analysis of embodied action (Goodwin, 2000), of actions with objects, and of technologies in action has been massively developed in workplace studies (Button, 1993; Suchman, 1996; Luff, Hindmarsh \& Heath, 2000; Heath \& Luff, 2000) aimed at examining occupational and expert practices, which often occur in complex spaces - called "coordination centres" by Suchman (1996) - involving sophisticated information and communication technologies. One of the goals is to show how action uses the possibilities and limitations of technology as situated resources, which in turn contribute to shaping them (Mondada, in press). 
Inspired by Actor-Network Theory, and the study of collective scientific and technical activities such as scientific cooperation networks (Vinck, 1999; Vinck, Kahane, Laredo, \& Meyer, 1993;) and product-design processes in the manufacturing industry (Jeantet, 1998; Vinck, 2003; Vinck \& Jeantet, 1995;), the notion of "intermediary object" refers to a physical entity that connects human actors. Latour (1987) showed that the monitoring of recorded data (drawings based on analysis instruments, tables of figures, diagrams, and texts) provides a different perspective on the analysis of scientific practices and gets past epistemological questions. Investigations into scientific and technical practices have shown that actors rely heavily on such intermediary objects, setting them up, making sure they are passed on to others, and generally making use of them. In design activities, intermediary objects supply a channel for many important interactions. They are used to back up action, convey information, make intentions or compromises come true, impose constraints on actors, mediate between diverging logic-based actions, and so on. They represent a virtual object that has yet to be manufactured. By way of these representations, actors assume they will be able to communicate their idea of the problems they have to solve, the possible solutions, and the constraints to be taken into account. Intermediary objects mediate the way each specialist expresses him/herself and the setting-up of a compromise. When the object is robust enough to support interactions between various social worlds, they can be called boundary objects (Star \& Griesemer, 1989).

The circulation of objects constitutes an area of collective action. Looking at intermediary objects thus provides a means of understanding a large part of professional activities; it reveals the organization of these practices, the distribution of tasks, their sequencing, and the areas where regulation between actors takes place. Following objects provides a means for analyzing how the actors' different interpretations and perspectives on the object are uncovered. The present investigation records the multitude of adjustments that take place throughout these ongoing dynamics. They are useful indexes for studying actionbased logic, conventions, and power struggles. They also mark the transition from one stage to the next.

As ending points, objects reflect agreement among the actors, and materialize that agreement in the form of an artifact. They become representatives of the actors who contributed to build them, and they are used by other actors who have to interpret them and change them into something else. They offer anchor points, new points of departure, and future perspectives all the while limiting the possibilities for action. Their agentivity (Latour, 1996) relates to the fact they sometimes carry more things than intended by the actors. They have unforeseen effects. If actors work so hard to "discipline" them, it is precisely because they are always in danger of slipping out of their control and introducing some new element into the action.

\section{"Prescription" versus "Ordonnance"}

In order to develop our conception of how objects are dealt with within an activity, we will concentrate on a second excerpt that immediately followed the first. We will see that the agreement reached with some effort in the first excerpt is immediately destroyed by the fact that the conditions under which it could work did not hold up for long - as if the objects and the complexity of their situated use resisted all attempted oversimplifications.

We will use these two excerpts, chosen from among a set of very rich field materials, to propose a detailed analysis that shows how the processes involved in the use and design of 
objects can be observed as they actually appear during, and while constraining, the interaction. The exact conditions, positions, environments, and modalities in which the relevance of objects emerges within interactions fundamentally interest us. Descriptions based on a single transcript allow us to identify processes in their making and the dimensions that constitute them. In this sense, the procedural mechanisms by which objects are used, are made relevant, and constrain the course of action are not just those at play in this particular excerpt; they have a more general scope. Failing to look at the details of how they are manipulated and transformed, would mean side stepping-and thus making unavailable for analytical scrutiny - their embodied and situated properties, i.e., it would mean pursuing a simplification of their use and power.

In the second excerpt, we will take into consideration not only how the participants refer to and categorize various objects during talk-in-interaction, but also how those objects are materially designated and called up during the meeting. To do so, we will propose the transcribed excerpt in its entirety. We will refine it later, with references to gestures and object manipulations.

Excerpt 2 (tape 1/11'30)

1 LAM le le noyau/ (.) du du système/ il a l'air de fonctionner/ the the corel (.) of the the system/ it seems to work/

2 le problème c'est son intégration en amont et en aval $\backslash$ (.) the problem is incorporating it upstream and downstream $\backslash$ (.)

3 [est-ce qu'on peut le dire ça/ (.) [le maniement interne [can you say that/ (.) [the internal processing

4 REG [l'accès/ le: le maniement interne quand [même/ (.) parce que [accessing/ the: the internal processing any [way/ (.) because

5 à partir du moment où on a euh (.) par exemple on fait starting from when you uh (.) for example you do

6 la prescription $\backslash{ }^{\circ}$ ça on: (.) on va $l^{\prime}$ voir $/{ }^{\circ}=$

7 LAM $=$ oui the prescription ${ }^{\circ}$ that you: (.) you'll see ${ }^{\circ}=$

8 REG produits sanguins labiles/ (.) euh la tendance ça serait de unstable blood products/ (.) uh you might have a tendency

9 cliquer et envoyer/ en fait non $\backslash$ il faut transformer cette to click and send/ but you can't you have to convert this

10 eh cette prescription en ordonnancel huh this prescription into an order

11 LAM oui mais ça on est yes but that we're

12 STE oui mais bon yes but well

13 LAMon est encore sur du pro- on [est encore sur une base de test là 14 STE we're still in a pro- we ['re still on a test basis here [non non [no no

15 STE non non là là je prends la parole ${ }^{\circ}$ parce que ${ }^{\circ}$ excuse-moi $\backslash$ (.) là on no no now now it's my turn to talk because ${ }^{\circ} I$ 'm sorry (.) here we est k- dans le coeur du logiciel ((clears throat)) nous on are $k$ - in the heart of the software $\backslash(($ clears throat $))$ we

17 a une commande/ (.) on a une commande qui e- qui émanait euh have a command/ (.) you have a command that w-that was coming from huh de la cellule transfusionnelle/ et la commande c'était/ (.) voilà 
and the command was/ (.) that's comment i faut faire $\backslash$ (.) une fois que vous avez fait la how you've got to do it (.) once you've done the

20 prescription vous faites l'ordonnance et l'ordonnance/ (.) .h prescription you do the order and the order/(.).h

21 vous la faxezl

$22 \quad(2)$

23 c'est la commande qu'on a qu'on a reçuel euh donc forcément it's the command that we that we received uh so necessarily

24 lorsque vous avez fait vos clics/ when you're done clicking

$25 \quad(2)$

26 l:a:: et puis c'est la réglementation/ j'pense que le docteur the: and besides it's in the regulations/I think doctor

27 Rioux va ressortir la (régle)[mentation/ 28 REG Rioux will bring up the (reg)[ulations [no it's not in the regulations [non c'est pas la réglementation

29 STE de sortir la: l'ordonnancel mais bien sûr que si/ to print out the the: order oh yes sure it is/

30 l'ordonnance papier doit être [maintenue dans le dossier euh 31 REG the paper order has to be [kept in the file uh

32 STE papier [(du patient) [oui mais euh [yes but uh chart [( of the patient) [non mais ça chacun [no but that everybody

34 REG ça/ ça c'est quoi/ c'est c'est une or[donnance ((shows y. sheet))

35 TER that/ what's that/ it's it's an or[der ((shows the yellow sheet))

36 REG c'est une fiche de prescription\\# [(ben) c'est une ordonnance [(well) it's an order

im it's a prescription sheet

\#image 1

37 STE ben c'est ça qu'vous sortez/ well that's what you print out/

38 REG et on envoie une fiche/ (.) de prescription/=

39 STE =oui and you send a prescription/(.) sheet/=

40 REG làl et pourquoi avec le logiciel on n'envoie pas la fiche here $\backslash$ and why with the software you don't send the

41 de prescription/ on envoie une ordonnance/ prescription sheet/ you send an order/

42 LAMnon i parle de (nombres) $/{ }^{\circ}$ enfin j'veux dire ${ }^{\circ}$ c'est $^{\circ}$ no he's talking about (numbers)/ ${ }^{\circ}$ um, I mean ${ }^{\circ}$ it's c'est un problème de terminologie/ it's a question of terminology/

44 REG oui mais/ [pour passer de de la fiche de prescription/

45 STE [XXXx ok butl [to go from from the prescription sheet/

46 REG y a une manoeuvre informatique/ pour (.) transformer ça en ordonnance there's a computer operation/ to (.) convert that into an order

47 STE hum hum hum $\mathrm{hm} \mathrm{hm} \mathrm{hm}$

48 REG parce que si on clique imprimer sur la fiche de prescription/ 
because ifyou click print on the prescription sheet/ on a trois mètres qui sortent

50 you'll have three meters (of paper) coming out

$51 \mathrm{LAM}^{\circ}$ oui c'est vrai aussi ça parce que c'est [un $\mathrm{xxx}^{\circ}$

52 REG yeah that's true too that's because it's [a $x x x^{\circ}$

53 on a euh transformé la fiche de prescription en [et à partir du moment où [and once

the prescription sheet into

54 ordonnance/ (.) après/ (.) euh:: (.) on ferme l'ordinateur/ (.) an order/ (.) then/ (.) uh:: (.) you shut down the computer/ (.)

55 il s'écoule quelques fois quelques heures/ avant de recevoir sometimes hours go by/ before you receive

56 parce que: les produits sanguins/ h et là/ pour retomber (.) sur la because: blood products/.h and herel to get (.) back to the

57 fiche/ (.) sur laquelle les infirmières/ (.) peuvent/ (0.5) euh: sheet/ (.) on which the nurses/ $\quad$ (.) can/ $\quad(0.5)$ uh:

58 mentionner les numéros euh des lots/ là il y a à nouveau un write in the numbers uh of the batches/ here again there's an

59 problème d'accès qui n'est pas évident। access problem that's not simple

60 DIL attendez moi je comprends pas/.h vous avez parlé une fiche de wait a minute I don't get it/ .h you talked about a

61 prescription et d'ordonnancel est-ce que: j'ai pas très bien prescription sheet and an order is it: I didn't really

62 compris ce que vous avez dit à propos de de la fiche de prescription understand what you said about the the prescription sheet

63 REG c'est pas celle-ci qu'on imprimel

it's not this one you print

64 DIL non mais/ ce document jaune/

65 REG oui/ no but/ this yellow document/

66 DIL on a pas essayé de vous l'reproduire ce documentl we didn't try to reproduce this document for you

67 REG [non non non ça c'est [no no no that it's

68 TER [non non non [no no no

$69 \mathrm{X} \quad$ [non non ça c'est clair [no no that's obvious

70 REG ça c'est le: c'est l'ancien that it's the: it's the old one

71 DIL d'accord d'accord okay okay

72 REG oui oui c'est l'ancien uh huh it's the old one

73 DIL d'accord bon okay so

74 STE mais quand vous dites fiche de prescription c'est ça ((shows doc 1)) but when you say prescription sheet it's this ((shows doc 1))

75 (2) ((REG bends over the table))

76 REG OUI/ YES/

$77 \quad(2)$

78 REG oui c'est ça yes that's it 
79 STE ce que vous imprimez c'est ça\ ((shows doc 2)) what you print is that ((shows doc 2))

80 (3) ((REG bends over the table))

81 REG oui c'est çal yes that's it

82 STE alors rien ne vous empêche aujourd'hui/ euh:: peut-être/ (.) so nothing is stopping you today/ uh:: maybe/ (.)

83 d'imprimer ça/ et d'envoyer ça/ ((shows doc 1$))$ from printing that/ and sending that/ ((shows doc 1))

84 REG oui mais vous allez [voir tout c'qui va so[rtir

yes but you'll [see everthing that'll co[me out

85 LAM [ça [ça fait trois mètres

[it'll $\quad$ [it'll be three meters

86 STE ouais mais:/ (.) attendez (.) là encore il faut/ y a p'têt yeah but:/ (.) wait $\quad$ (.) here again there're/ ther're maybe

87 des choses à corriger dans le coeur du: logiciel/ mais/ (.)

some things that have to be corrected in the core of the: software/ but/ (.)

88 nous on a fait ce qu'on nous a demandé de faire/ c't'à-dire
we did what we were asked to do/ which is

89 LA vous remplissez l'ordonnance/ ((shows doc 1)) lorsque -fin HERE you fill in the order/ ((shows doc 1)) when-mean

90 vous remplissez la fiche de prescription/ ((shows doc 1)) you fill in the prescription sheet/ ((shows doc 1))

91 et c'est l'ordonnance qu'on envoiel ((shows doc 2$)$ ) and it's the order you send ((shows doc 2))

92 si vous nous dites la fiche de prescription qu'on envoie/ on if you tell us (it's) the prescription sheet you send/ we

93 s'en fout complètement nous [xx ((shows doc 1))

94 REG we couldn't care less (we) [xx ((shows doc 1))

95 sorte que l'imprimante euh s'arrête au bon endroitl [oui mais il faudrait faire en [yes but you'll have to find

a way to make the printer ehm stop in the right place

96 parce que: je sais pas si ça a été transformé/ mais: on

97 imprimait tout printed everything $\backslash$

98 LAM ouais mais/ (.) ça c'est/ ça c'est leur problème ((points to STE)) yeah but/ (.) that's/ that's their problem ((points to STE))

99 STE ((clears throat)) la la seule chose que j'ai dit à à monsieur là ((clears throat)) the the only thing I said to to this man here

$100 \quad$ ((clears throat))

$101 \quad(1)$

102 vous nous donnez/ (.) une bonne fois pour toutes

103 (1) just tell us/ $\quad$ (.) once and for all

104 ce que je vous voulez fai:re/ et on le fait (.) mais/ what you want to d:ol and we'll do it (.) but/

105 RIOon est aussi là pour ça that's what we're here for too

106 STEon ne fait pas des zig/ (.) et des zag\ we don't bumble/ (.) around

107 RIOon est aussi là pour ça that's what we're here for too

108 STElà nous on a (eu) une commande/ (.) on a fait la commandel here we have (had) a command/ (.) we did the command

109 qu'on nous a/ (.) demandéel we werel (.) asked to do 


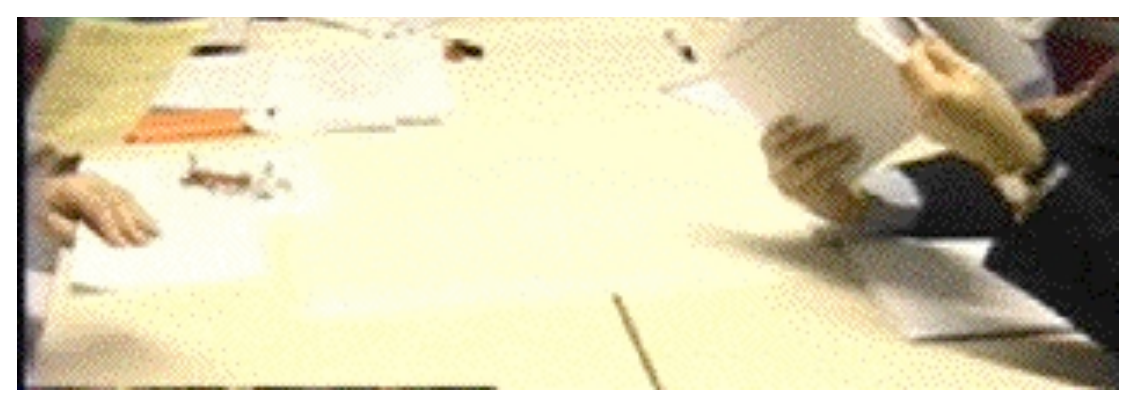

image 1

In this excerpt, the consensus established by Lamblet (LAM) is not held for very long in the confrontation between the system's user, Régnier (REG), and the system's designer, Steiner (STE). We will try to understand the praxeology of this disagreement, which has to do with divergent conceptual as well as material and practical views on two related, indissociable, but yet different objects: "prescription" and "ordonnance." Since the status of these objects undergoes continuous changes within the action, we will not try to translate or clarify their meaning once and for all, but will use the same original categories as the participants, trying to reconstruct the meanings they successively attribute to them.

The re-emergence of disagreement [1-33]

The beginning of the second excerpt immediately follows the ending of the first. Lamblet makes a proposal (1-3) aimed at reaching an agreement, even if only a minimal one, about the positive evaluation of the system (of his "core") [1]). This statement is aimed especially at Régnier (3): Lamblet asks Régnier to ratify it, and in doing so, presents the importance of sharing his statement, which is to be achieved by obtaining the acceptance of the other actors. Instead of subscribing to Lamblet's projection of a minimal agreement, Régnier produces an overlapping reply (4) that raises a new issue. In this manner, Régnier gradually introduces a point of disagreement, which is built up from an opposition (8-10) between "you might have a tendency to click and send/" (8) and "you have to convert this prescription into an order" (9-10), the two assertions connected with the particle "no" (9). Régnier thus pinpoints two procedures which he differentiates and which will trigger a lengthy discussion about the contrasted terms, "prescription" and "ordonnance."

Right away, Régnier's objection is received in different ways: first, by incomplete turns at talk by Lamblet (11) and Steiner (12) marked by a typical dispreferred format ("yes but"), and second, by Lamblet's attempt to play down the status of the system (he is no longer talking about the "core" but about the "pro-", which is probably the first syllable of "provisional" or "prototype," and about the "test"; this recategorization of the system insinuates that the objection is about a fixable detail, and this opens up a negotiation to that effect). By contrast, Steiner reacts in a very different way (beginning with "no no" [15]) and re-asserts, on the contrary, that the problem is central (and not marginal) ("we're k- in the heart of the software" [16]). While Lamblet points out the possibility of a conversion, Steiner defends the device as it is, relying on the previous act of "commanding" (17-24) and restating the fact that the device conforms to that command. In other words, he brings another actor into the picture, and in doing so shows that the legitimate frame of reference for evaluating the device is not the user but the orderer. By invoking the command, Steiner reformulates the task Régnier had mentioned in his objection: "that's how you've got to do it $\backslash$ once you've done the prescription you do the order and the order / you fax itl" (18-21). This reformulation is interesting in several respects: firstly, it is stated in a prescriptive fashion ("you've got to do it"), and secondly, it defines the sequence of a series of actions imputed to "you" (in the second person, here, addressing Régnier) and spread out over time (the prescription $\rightarrow$ the order $->$ the fax). This sequencing of actions is in sharp contrast with the "tendency" invoked 
by Régnier, who outlines another series of actions (click $->$ send [9]). This reply, which, by way of the command, rejects Régnier's position, receives no reaction at all from either Régnier himself or Lamblet (22), despite Steiner's new attempt to prompt a response (23-24), which is answered by a silence (25).

The discussion only resumes through the introduction of a new aspect, "the regulations" (26-27), ascribed to Régnier, who allows Steiner to reinforce the importance of the "paper order" and thus of the middle phase of the three successive actions he just sketched out. Here again, Régnier's reaction is an explicit disagreement ("no it's not in the regulations" [28]), to which Steiner replies, speaking at the same time ("oh yes it is" [29]). The disagreement between them is quite clear.

Régnier proceeds (34) to make a move that breaks away from the chain of negations in the preceding turn, by shifting from the argument that just took place to pointing at a document. There is thus a change in the mode of discussion and a shift from an exchange that brought up referents verbally (the referents are discourse objects) to an exchange that brings up referents via the gestural modality (the referents are material objects that are present and pointed to on the table). This second interaction mode will be initiated twice, the first time by Régnier (34) and the second time by Steiner (74). We will take a close look at these two moments, which grant a fundamental role to artifacts.

Régnier's overt use of the yellow sheet [34-54]

On line 34, Régnier initiates a new sequence, with a description, using a deictic term "ça" ("that") and showing a yellow sheet he has just taken out of a pile of documents in front of him. "Ça" is categorized first as an "ordonnance" by himself in an interrogative mode and by the nurse (as Régnier holds the sheet up in front of him), and then as a "fiche de prescription" in a subsequent repair (as he shows the sheet to the co-participants) (36) (see image 1). Steiner immediately equates this object with the one printed by the software ("well that's what you print out/" [37]), again using the deictic term "ça" (and not the name). Régnier, who is still holding the yellow sheet, produces a second descriptive turn (38), using the term "fiche de prescription" once again, with which Steiner agrees on his next turn (39). This local agreement is destroyed by Régnier's subsequent turn (40-41): whereas Steiner equates the exhibited object with the formalized one produced by the computer, Régnier differentiates them, introducing a difference between "fiche de prescription" and "ordonnance," and claiming that when using the software the doctor sends the latter, not the former.

Lamblet tries to dismiss this distinction as being just a "terminological" problem (43), but Régnier insists (44), pointing out that the conversion of the former into the latter necessitates an extra operation using the software. So, Régnier shows the yellow sheet in order to speak about another set of objects and practices which is supposed to replace the sheet but is not equal to it, contrary to what Steiner suggests. This is done using the gesture that "animates" the yellow sheet (for transcript conventions concerning gestures, see the end of the paper):

(from excerpt 2, lines 44-46) 
REG oui mais/ pour passer de de *la fiche de prescription/* (.)

*UNDERSCORES THE TITLE “F. DE P." * ON THE TOP OF THE YELLOW SHEET--*

y a une manoeuvre informatique/ *pour (.) transformer**ça/ en ordonnance*

*WIDESEMICIRCULAR GESTURE* *HOLDS IT*

FROM RIGHT TO LEFT----------*

Régnier's gestures use the yellow sheet to materialize the starting point of a conversion process iconically represented by a semicircular hand movement that ends at a point on his left (the "ordonnance"). The conversion is thus spatialized by Régnier's gestures. In subsequent referential gestures, Regnier will use this same gestural space again (for uses and conservations of diagrams drawn gesturally in the air, see Enfield, 2003; Liddell, 1995). He again emphasizes the same point on the sheet when he speaks of the formalized "fiche de prescription" (which he does clearly on line 48, and faster on line 53), and he once again points to the same location on the table to his left when mentioning the "ordonnance" (54). Thus, the conceptual distinction Régnier is making - in order to demonstrate and criticize the added complexity of the software - is materialized in gestures and locations using an artifact that precisely escapes his critique.

Steiner's use of his powerpoint documents [54-85]

While Régnier is explaining further complexities of the software (54-59), Steiner looks through his own stock of documents. He continues to do so as a question being raised by Dillet (a computer engineer) - which interestingly brings out his difficulty understanding Régnier's distinctions and proposes a clarification of the status of the yellow sheet as an "older document" (60-73). During the sequence initiated by Dillet, Steiner reads and arranges his documents. This activity is both very distinct from Régnier's concealment of the nolonger-useful yellow sheet, and similar to another participant's (Rioux) picking up and reading through his own documents. Régnier has created the opportunity for a mode of discussion based on the showing of various objects. Steiner brings to bear other documents exhibiting his preparatory activity during the sequence opened by Dillet. All this creates a "contextual configuration" (Goodwin, 2000) where documents are moved, reordered, and significantly positioned on the table for the sake of the ongoing argumentation - not only on the part of the speakers, but also of all participants around the table who begin to search through their own documents (see also Streeck, 1996). This contextual configuration, which makes the document uses relevant, is acknowledged by Régnier who gets out his glasses even before Dillet's sequence is closed (70), as if he were adjusting very early to the possible next move.

Indeed, the next sequence is initiated by Steiner (74) with a gesture very similar to Régnier's initiation of the previous one (34):

(from exerpt 2, lines 74-85)

74 STE mais quand vous diфtes fiche de prescription c'est $\phi$ ça $\phi$ TAKES DOC 1, MAKE A WIDE SEMI-CIRCULAR $\phi$ HOLDS DOC---> $\phi$ GESTURE FOR PUTTING IT IN FRONT OF REG $\phi$

$75 \mathrm{REG} *(2) * \#$ 

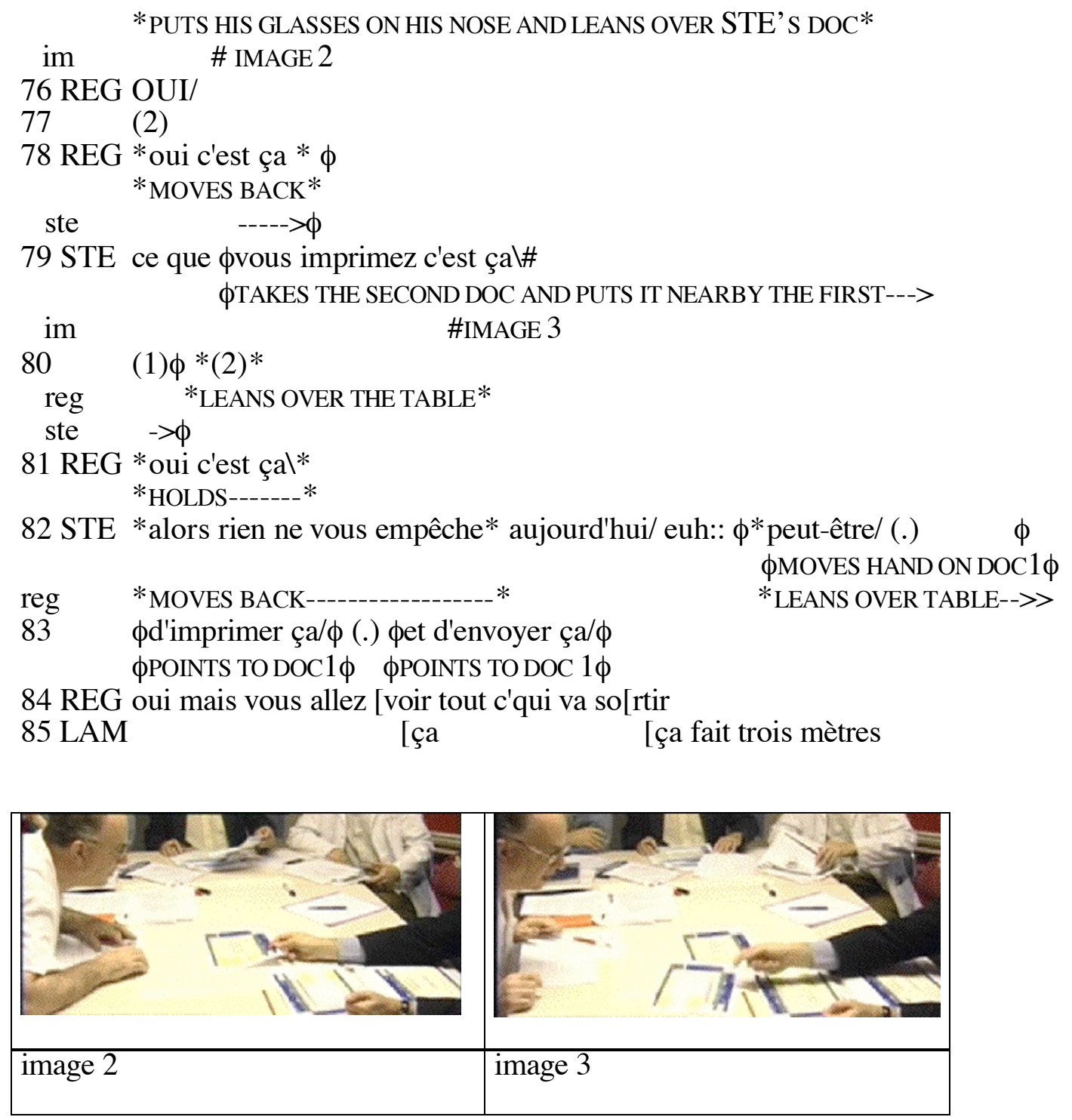

Steiner puts two documents on the table, in an overt way and with an emphatic gesture (like shuffling cards on the table), and then turns to Régnier $(74,79)$. The documents are powerpoint slides, containing the forms produced by the computer program. Twice, Régnier leans overtly over the table to recognize each document and moves back to his original position. Both movements accompany a request for confirmation, by which Steiner translates Régnier's categories ("fiche de prescription" and "what you print") into a new materialization, a representation of the electronic prescription and its printed version. In this way, Steiner goes along with Régnier's differentiation, adopting it for his own documents. He also goes along with Régnier's previous statement ("you might have a tendency to click and send/" 8-9), thereby concentrating the manipulations of the same object. He does this in a proposal (82), firmly formulated first and then rephrased in a modalized way ("uh:: may be/ (.)" [82]) by pointing twice with his pen to the same document (83). To some extent, Steiner is using his first document in a way similar to Régnier's use of his yellow sheet.

Régnier, supported by Lamblet (85), rejects the suggestion, repeating his critique of the system: if the user checks off a series of products on the "fiche de prescription" and then prints it, he obtains a long list of all eligible products and not (as in the "ordonnance") a short list containing only the selected ones. This difference is relevant and visible on the (new) 
electronic sheet (where the user has to check off items on a list) and not in the (old) yellow sheet (where the user has to write in the items he needs). In the new system, then, two distinct files have to be handled, whereas in the old system a single object contained two final, detachable documents, thanks to the old carbon copy system.

\section{The limits of the negotiation [86-109]}

This debate confronts and partially superimposes various referential realms, anchored in various contexts of practice. Régnier speaks of "prescription" and "ordonnance" as two distinct entities, but he himself and also the nurse (34-35) erase the distinction, which is questioned by Dillet, dismissed by Lamblet, and self-repaired by Steiner (89-90). Each actor points to different objects in order to refer to these two entities: these objects constitute their representations, not their materializations. And each person tries to bring to bear practices where these entities are either unified or separate. But each one does so within his or her own sphere, mobilizing objects related to his or her professional expertise, and thereby displaying their distance from each other through their bodies and the spaces they occupy.

Régnier's criticism of the software is repeatedly categorized by Lamblet as marginal and by Steiner as central. On Steiner's side, this produces a refusal to consider any change and repeated references to the original "commande": note that every time Steiner points out that the criticism of the system is central, he does not address it directly but instead refers to the initial command (16-17, 109). Interestingly, when referring to the initial command, Steiner repeats and maintains a strict distinction between "prescription" (to be filled in) and "ordonnance" (to be sent) (19-20, 90-91). This reference displaces the problem by no longer focusing on the user and his difficulties but on the administrative hierarchy. Régnier's criticism and request unify both the acts and the objects (i.e., the possibility of filling in and printing the same file), and refer to a different view of actual medical practices.

\section{The systematic production of disagreement}

In this paper, we analyzed a fragment of a meeting where attempts to come to an agreement accompanied by misaligned moves are repeatedly accomplished by the participants. These attempts and the responses they obtain shed light on the mechanisms underlying the production of a shared view of problem solutions. The common definition of the situation is not the condition for a successful discussion; on the contrary, a common definition has to be achieved through and by means of discussion - and this will be crucial for the potential continuation of a common project that can be further developed in a collaborative way. The moment we analyzed here gives us a glimpse of how, in this case, the medical staff and the computer staff were unable to achieve a common view of their mutual involvement in the project. Our method of analysis emphasizes the importance of the sequential organization of the turns at talk.

For instance, the turns in which Lamblet is summarizing the situation so as to achieve a minimal agreement (at the end of Excerpt 1, beginning of Excerpt 2) are the end and the result of the extended sequences that precede it, sometimes suspended or deviated by other inserted sequences. In this sense, these turns appear to be summarizing the positions set forth, and have a closing effect on the current phase of the activity: they are located at a specific point in the sequential unfolding process, in a place where the joint arrival of all participants at this momentary closing point has been organized (Schegloff \& Sacks, 1973). This attempt 
to stabilize a mutual agreement is also the beginning and the condition for initiating the next activity phase, where the agreement reached can be the basis for further developments. In this sense, the summarizing turns claiming that there is an agreement project more to come: either turns displaying agreement (for the difference between claiming and displaying agreement see Lynch, 1985) - for example, turns initiating the collective development of a topic - or turns contesting the recapitulation - for example, turns introducing a new difficulty. This is precisely what happens at the beginning of Excerpt 2, where Régnier adds a new problematic element instead of falling in line with what Lamblet says in his turn.

In this sense, what is considered and dealt with by the participants as a "problem," a "difficulty," an "obstacle," is locally defined by the very way in which they produce their next turns; it is also the result of local (and potentially divergent; see Lamblet line 13 versus Steiner line 16) categorizations of a new topical entity as one that is "central" or "peripheral" to the topic being discussed, and as such, as one that constitutes a "marginal" or "fundamental" criticism. In our analysis, we have tried to follow the methodical organization of these various attempts to limit or expand divergent accounts of what is going on and what has been done.

\section{Flexible transformations of artifacts-in-action}

Our analysis focuses on the sequential organization of a fragment of a discussion, but also reveals the multimodal dimension of its organization. The sequential unfolding of the discussion is not only based on linguistic resources but also mobilizes multimodal resources such as bodily postures, gestures, and artifacts.

The way in which artifacts are brought to bear in this discussion sheds a light on the malleability of these objects within the course of action, and has a number of analytical and methodological consequences. The role of objects is now acknowledged in the literature, but it has not yet given rise to a systematic account of how these objects are configured, categorized, and used locally within actions, i.e., in the reflexive definitions of actions and objects, each one mutually shaping the other. In the fragment we studied, various objects were used; our analysis focused on Régnier's yellow sheet and on Steiner's printed powerpoint slides. These objects cannot be qualified and categorized once and for all by the analyst, since they change with the sequential positions in which they are invoked within the activity that uses them, and within the gestures and movements that mobilize them. For instance, Régnier mobilizes his yellow sheet in different ways: by just sketching out the move of removing it from the pile of documents where it was inserted and hidden, by holding it up in front of the audience, by showing it to Steiner, by pointing to a particular line while speaking. In each case, the document has a different kind of visibility, a different status as an object publicly displayed. The detailed make-up of the object can be rendered irrelevant (as in the vague and interrupted removal of the invisible document from the pile) or, on the contrary, can be pointed to and made relevant (when Régnier emphasizes "fiche de prescription" while referring to it with this name). Documents can be shown from afar, from within his personal space, as was Régnier's yellow sheet, or can be shown in an adresseeoriented way, as were Steiner's PowerPoint prints put in front of his interlocutor and displayed in view of being read. Each categorization of the object is accomplished by a specific gesturality, and reflexively reshapes the contextual configuration of the table as a differentiated public space. 
Mobilizing documents plays an active part in the sequential organization of the talk: documents can be referred to without being shown, and the sheer act of holding up a document or putting it in the middle of the table accomplishes an accountable move within the discussion. Displaying objects - even if they are not the objects the talking is about - is a powerful way of producing evidence. In the case analyzed here, we have seen that although objects are used in this way, they do not always produce the expected consequences. For instance, Steiner displays two documents but then points twice to the first one, thereby recognizing that one document may be enough - which is precisely the point Régnier is trying to make. Objects create evidence that is not always the same as the evidence the participant's actions were aimed at creating. In this sense, they shape the action and are shaped by it.

\section{Concluding on Objects and Multimodality}

This paper focuses on the articulation of objects, gestures, and talk during collective activities in situ. Our interdisciplinary attempt is inspired by contemporary paradigms that address human activity and recognize the importance of artifacts. Tackling an empirical case, our analysis provides an opportunity to discuss the interrelationships between artifacts and multimodal collective practices.

We have brought to the fore the ecology of action and interaction by explicitly taking artifacts and gestures into account. The analysis reveals the sequential unfolding of the discussion based on the interweaving of linguistic practices and postures, gestures, and artifacts. It focused on the achieving a (dis)agreement, and on the multimodal practices that produce misalignment. The paper showed that some objects are defined praxeologically and contextually both as categories ("ordonnance" and "prescription") and as artifacts (their plasticity mobilized in interaction). These artifacts were, in this case, intermediary objects that mediated the way each specialist expressed him/herself and tried to configure the interaction dynamics so as to reach a conclusion. The artifacts were not effective instruments for fulfilling a function specified once and for all. They were mobilized and redefined as the discussion unfolded and as physical moves took place, thereby establishing their plasticity within the course of the action. They were locally configured, categorized, and used in action at the same time as they contributed to configuring the dynamics, postures, talk, and accomplishments taking place therein. These objects could not be qualified once and for all, neither by the actors nor by the analyst, but changed with the sequential positions in which they were engaged. Their qualities varied according to the categorizations they underwent via talk and gesture. They participated in the configuration of the physical and collective space, which was divided up and rearranged.

This paper showed that artifacts are defined not only through their design and circulation, but also through a subtle interweaving that includes gesture and talk; they are malleable, not only when there are broken down and rebuilt, and when their meaning changes, but also through their involvement in a local configuration of people and artifacts, and in a sequence of postures, gestures, and talk. It also showed that artifacts are neither mere instruments in the service of an ongoing practice nor vectors of a social history, which would make things and persons asymmetrical. In some circumstances, the configuration - made up of talk, postures, and artifacts - escapes from the subject's orientation toward objects. Objects create evidence that is not always the same as what the participants want to create. In this sense, they configure and are configured by action. They can even acquire some autonomy from the actors who made them. 
By bringing to bear the intersecting views of the linguist, the sociologist, and the psychologist, this interdisciplinary study shows that the interweaving of the discursive, gestural, and artifactual registers is at the core of the group's activity during the session analyzed here. A sequence of utterances connected to each other can only provide a scaffolding for the construction of meaning (Bruner, 1990) because they are deeply anchored in an embodied relationship incorporated in artifacts and distributed among persons and objects. Objects and properties in the material environment are reflexively constituted in, and by, verbal interaction. Conversely, discursive elements acquire their interactive statuses solely in, and by, their relationships to the ambient "artifactuality." A social interaction, the locus of knowledge generation, is a dynamic that comes to be via the shaping of forms forms of language, forms of bodies, and forms of artifacts. Humans and non-humans (Latour, 1999) were at the heart of this collective practice here, which engendered the history of this particular work group.

\section{Transcript conventions}

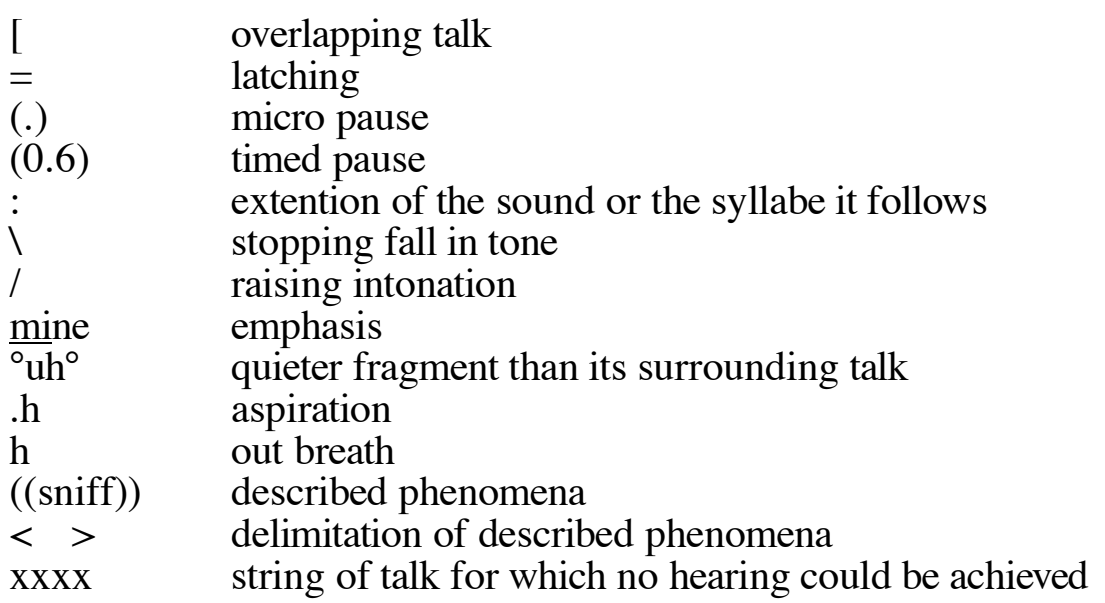

Descriptions of gestures and actions are transcribed according to the following conventions:

$\begin{array}{ll}* & \begin{array}{l}\text { a gesture is delimited between two symbols } \\ \text { and synchronized with corresponding stretches of talk } \\ \text { the participant making the movement is identified in the margin } \\ \text { if }(\mathrm{s}) \text { he is not the same person as the actual speaker } \\ \text { the temporal location of the screen shot is indicated within the turn }\end{array} \\ \text { im } & \begin{array}{l}\text { gestures and movements are described in small capitals } \\ \text { the gesture is held until the next closing boundary symbol } \\ \text { the gesture is held until the next symbol, situated on the following line } \\ ----\end{array} \\ ---> & \begin{array}{l}\text { the gesture is held until after the end of the excerpt } \\ \text { gesture preparation } \\ \text { gesture retraction }\end{array}\end{array}$

An indicative translation is provided line per line (in italics), in order to help reading the original. 


\section{References}

Béguin, P., \& Rabardel, P. (2000). Designing for instrument-mediated ctivity. Scandinavian Journal of Information Systems, 12, 173-190.

Berg, M. (1997). Rationalizing medical work: Decision-support techniques and medical practices. Cambridge: Massachusetts Institute of Technology Press.

Brassac, C. (2006). Computers and knowledge: A dialogical approach. AI \& Society, 20 (3), pp. 249-270.

Bruner, J. S. (1990). Acts of meaning. Cambridge, MA: Harvard University Press.

Button, G. (1993). Technology in working order: Studies of work, interaction and technology. London: Routledge.

Callon, M., \& Law, J. (1982). On interests and their transformation: Enrolment and counterenrolment. Social Studies of Science, 12(4), pp 615-625.

Cole, M. (1996). Cultural Psycholog: A once and future discipline. Cambridge, MA: Harvard Univeristy Press.

Drew, P., \& Heritage, J. (1992). Talk at work. Cambridge: Cambridge Univeristy Press.

Enfield, N. J. (2003). Demonstratives in space and interaction: Data from Lao speakers and implications for semantic analysis. Language, 79(1), 82-117.

Engeström, Y. (2000). Activity Theory as a framework for analysing and redesigning work. Ergonomics, 34(7), 960-974.

Engeström, Y., \& Miettinen, R. (1999). Introduction. In Y. Engeström, R. Miettinen, \& R. -L. Punamäki (Eds.), Perspectives on activity theory (pp. 1-16). Cambridge: Cambridge University Press.

Engeström, Y., Miettinen, R., \& Punamäki, R. -L. (1999). Perspectives on Activity Theory. Cambridge: Cambridge University Press.

Garfinkel, H. (1967). Studies in ethnomethodology. Englewood Cliffs, NY: Prentice Hall.

Garfinkel, H. (1986). Ethnomethodological studies of work. London: Routledge and Kegan Paul.

Garfinkel, H., \& Wieder, D. L. (1992). Two incommensurable, asymmetrically alternate technologies of social analysis. In G. Watson, \& R. M. Seiler (Eds.), Text in context: studies in ethnomethodology (pp. 175-206). Newbury Park: Sage.

Goffman, E. (1971). The presentation of self in everyday life. Harmondsworth: Penguin.

Goodwin, C. (1981). Conversational organization: Interaction between speakers and hearers. NY: Academic Press.

Goodwin, C. (2000). Action and embodiment within situated human interaction. Journal of Pragmatics, 32, 1489-1522.

Heath, C. (1986). Body movement and speech in medical interaction. Cambridge: Cambridge University Press.

Heath, C., \& Luff, P. (2000). Technology in action. Cambridge: Cambridge University Press.

Hutchins, E. (1995). Cognition in the wild. Cambridge, MA: Massachusetts Institute of Technology Press.

Jeantet, A. (1998). Les objets intermédiaires dans les processus de conception des produits [Intermediary objects in the product design process]. Sociologie du Travail, 3(98), 291-316.

Kaptelinin, V. 2005. The object of activity: Making sense of the sense maker. Mind, Culture, and Activity, $12,4-18$.

Keating, P., \& Cambrosio, A. (2000). Biomedical platforms. Configurations, 8, 337-387.

Latour, B. (1985). Les « vues » de l'esprit. Culture technique, 14, 4-29.

Latour, B. (1987). Science in action: How to follow scientists and engineers through society. Cambridge, MA: Harvard University Press. 
Latour, B. (1996). Cognito ergo sumus! Or psychology swept inside out by the fresh air of the upper deck... [Review of the book Cognition in the wild]. Mind, Culture, and Activity, 3(1), 54-63.

Latour, B. (1996). On interobjectivity. Mind, Culture, and Activity, 3(4), 228-245.

Latour, B. (1999). Politiques de la nature: Comment faire entrer les sciences en démocratie [Politics of nature: How bring the sciences into democracy]. Paris: Éditions de la Découverte.

Lave, J. (1988). Cognition in practice. Cambridge: Cambridge University Press.

Leontiev, A. (1975-1984). Activité, conscience, personnalité. Paris : Editions Sociales.

Liddell, S. (1995). Real, surrogate, and token space: Grammatical consequences in ASL. In K. Emmorey \& J.S. Reilly (eds.). Language, Gesture, and Space (pp. 19-41. Mahwah, NJ: Lawrence Erlbaum Associates.

Luff, P., Hindmarsh, J., \& Heath, C. C. (2000). Workplace studies: Recovering work practice and informing system design. Cambridge: Cambridge University Press.

Lynch, M. (1985). Art and artifact in laboratory: A study of shop work and shop talk in a research laboratory. Boston: Routledge and Kegan Paul.

Mead, G. H. (1934). Mind, self and society from the standpoint of a social behaviorist. Chicago: University Chicago Press.

Mondada, L. (2006). Video recording as the preservation of fundamental features for analysis. In H. Knoblauch, J. Raab, H. -G. Soeffner, \& B. Schnettler (Eds.), Video analysis. Bern: Peter Lang Publishing.

Mondada, L. (in press). Operating together through videoconference: Members' procedures accomplishing a common space of action. In D. Francis \& S. Hester (Eds.), Proceedings of the IIEMCA Conference: Orders of ordinary action. Washington: University Press of America.

Nardi, B. A. (1996). Some reflections on the application of activity theory. In Nardi, B. A. (Ed.). Context and consciousness: Activity theory and human-computer interaction (pp. 235246). Cambridge, MA: The MIT Press.

Schegloff, E. A., \& Sacks, H. (1973). Opening up closings. Semiotica, 8, 289-327.

Star, S. L., \& Griesemer, J. (1989). Institutional ecology, 'translations' and boundary objects: Amateurs and professionals on Berkeley's Museum of Vertrebate Zoology, 1907-1939. Social Studies of Science, 19, 387-420.

Strauss, A., Fagerhaugh, S., Suczeck, B., \& Wiener, C. (1985). The social organization of medical work. Chicago: The University of Chicago Press.

Streeck J. (1996). How to Do Things with Things. Human Studies 19, 365-384.

Suchman, L. (1987). Plans and situated actions: The problem of human/machine communication. Cambridge: Cambridge University Press.

Suchman, L. (1996). Constituting Shared Workspaces. In Engeström Y., Middleton D. (eds.), Cognition and Communication at Work (pp. 35-60), Cambridge : Cambridge University Press.

Vinck, D. (1999). Les objets intermédiaires dans les réseaux de coopération scientifique. Contribution à la prise en compte des objets dans les dynamiques sociales [Intermediary objects in scientific cooperation networks. A contribution to taking objects into account in social dynamics]. Revue Française de Sociologie, 11, 385-414.

Vinck, D. (2003). Everyday engineering: An ethnography of design and innovation. Cambridge, MA: Massachusetts Institute of Technology Press.

Vinck, D., Kahane, B., Laredo, P., \& Meyer, J. -B. (1993). A network approach to studying research programmes: Mobilising and coordinating public responses to HIV/AIDS. Technology Analysis \& Strategic Management, 5, 39-54.

Vinck, D., \& Jeantet, A. (1995). Mediating and commissioning objects in the sociotechnical process of product design: A conceptual approach. In D. Maclean, P. Saviotti, \& D. 
Vinck (Eds.), Designs, networks and strategies (pp. 111-129). Bruxelles: EC Directorate General Science R\&D. 